\title{
Building Students' Characters Through Extracurricular Activities
}

\author{
Arita Marini \\ State University of Jakarta, Indonesia \\ arita250268@yahoo.co.id
}

\begin{abstract}
This research aimed to find out the ways to build the students' characters through extracurricular activities at elementary schools in Jakarta, Indonesia. This survey study was conducted at 63 elementary schools in Jakarta, Indonesia. Data collection was done through interviewing and observing. Building students' character in extracurricular activities was related to praying together, punctuality, discipline, active behavior, fun situation, teamwork, competition, rewards, character values, facilities, independences, and religious values. The result of this study showed that the mean of building students' character in extracurricular activities was 12.87 or 99 $\%$ of theoretically maximum score. Building students' character through extracurricular activities higher than average score reached $88.9 \%$ and less than average score reached $11.1 \%$. It can be concluded that building students' characters through extracurricular activities at 63 elementary schools in Jakarta in Indonesia has already been effective.
\end{abstract}

Keywords - students' characters, extracurricular activities, punctuality, discipline, active behavior, independences, religious values

\section{INTRODUCTION}

Building students' characters was done through theater of empowerment [1]. Students' characters were developed by doing theatrical activities. Characters improved in these activities were discipline, independence, patriotism, environmental care, and reading motivation. However, this study did not explain in detail the ways to build students' characters through these activities.

The study conducted [2] showed that implementing character education tended to improve students' academic scores. These activities improved a healthy moral character. However, this study only investigated that character building in intracurricular activities.

[3] Stated that character education as a subject showed importance in curriculum. This education aimed to improve students' behavior at school. Implementation of social emotional and character development in classroom was done by teaching, practicing, and modeling essential personal habits to make people good human beings. However, this education was involved in intracurricular activities.

The teachers gave their perception to plan and implement the character education. The teachers were able to teach, demonstrate, and model the behaviors expected done by the students. Characters built in the classroom curricula were integrity, responsibility, and respect regarded the most significant values. However, this character education was only incorporated into the classroom curricula [4].

Character education was integrated in teaching and learning process. Subject taught was related to the value and improving the daily life. Developing human character was done through changing curriculum, teaching and learning, evaluating, and habits of the teachers [5]. However, this study only examined integrating character values in classroom.

This study was to find out how to build students' characters through extracurricular at 63 elementary schools in Jakarta in Indonesia related to praying together, punctuality, discipline, active behavior, fun situation, teamwork, competition, rewards, character values, facilities, independences, and religious values.

\section{METHOD}

Students' characters were built through theatrical activities [1]. These activities built the characters through stakeholders involvement to monitor the students' characters leading to have strong characters. Theatrical activities make the students act in total and insert positive messages to them. After doing these activities, the students were familiar with the communities, more sensitive, and more sociable. Therefore the students' characters became stronger. However, there was no explanation in detail about how to build the character of the students related to the characters shaped.

There were positive correlation between character education and students' achievement [2]. This study showed that school was able to ensure clean and safe physical environment. In addition to this, good character education was promoted by the parents and teachers modelling. The school gave quality opportunities for the students to contribute meaningful ways to the community. However, this study did not examine the character education in extracurricular acitivites.

Character education in intracurricular activities was important to make peope good humanbeings [3]. In classroom, students was taught habits and skills related to good characters. Modeling character behavior for the students was beneficial in order that the students were not confused about appropriate or inappropriate behavior. However, character education was only discussed in intracurricular not in extracurricular activities.

Graff, C. E (2012) examined that the teachers were potential to develop students' character so that they had to be 
models of good behavior [4]. Incorporating character education into schools was done by improving school climate and culture, increasing teacher satisfaction, enhancing student achievement, and disruptive behaviors. Character education was conducted to prepare the students to behave and achieve at school. Character education aimed to make the students reflect morality and good values. This character education was planned to positively affect the students' behavior in schools. However, this study did not investigate character in extracurricular activities.

The study conducted by Dwirahayu, G (2011) showed that character values was not only in cognitive aspects, but also in social life. Character education was integrated into teaching mathematics. The syllabus, design, lesson plan, and material of mathematics were integrated with character education leading to the students having good characters such as critical thinking, talk less do more, hardworker, being confident, problem solvers, learn to communicate mathematically, and learn to reason mathematically. However, this study only investigated integration of character values in teaching learning process.

\section{RESULTS AND DISCUSSION}

This survey study was conducted for 63 principals at 63 elementary schools in Jakarta using observation instrument consisting of 13 items with dichotomy scale 0 and 1 . Score 0 means not good. Score 1 means good. Minimum theoretical score is 11 and maximum theoretical score is 13 .

Result of study showed that praying together before and after extracurricular activities was already done at $100 \%$ of 63 elementary schools. The students' presences was already on time at $98 \%$ of 63 elementary schools observed. The students participated in extracurricular activities regularly at $100 \%$ of 63 elementary schools. The students already participated actively in extracurricular activities at $100 \%$ of 63 elementary schools. Fun situation was already created in extracurricular activities at $100 \%$ of 63 elementary schools. Collaboration was already become accustomed in extracurricular activities at $100 \%$ of 63 elementary schools. The students participated in competition related to the curricular activities they were interested in at $100 \%$ of 63 elementary schools observed. Students' achievements in competition related to curricular activities was displayed at $98 \%$ of 63 elementary schools. Character values was already internalized in curricular activities at $100 \%$ of 63 elementary schools. Facilities already supported extracurricular activities at $100 \%$ of 63 elementary schools. Scores of extracurricular activities was included in the students' report at $100 \%$ of 63 elementary schools. Students' independences and discipline was already integrated by students participating in camping trip at $97 \%$ of 63 elementary schools. Religion based curricular activities was done at $94 \%$ of 63 elementary schools.

Based on empirical data, survey result of principals' competences to manage characters-base extracurricular activities was shown in Table 1.
Table 1: Descriptive statistics of scores in managing character based extracurricular activities

\begin{tabular}{llc}
\hline \hline No & Descriptive Statistics & Scores \\
\hline 1. & Mean & 12.87 \\
2. & Std. Error of Mean & .048 \\
3. & Median & 13.00 \\
4. & Mode & 13 \\
5. & Standard Deviation & .381 \\
6. & Sample Variance & .145 \\
7. & Range & 2 \\
8. & Minimum & 11 \\
9. & Maximum & 13 \\
\hline
\end{tabular}

In Table 1, it is shown that mean of character based extracurricular activities is 12.94 or $99 \%$ from theoretical masimum score achievement. It means that principal competences in managing character based extracurricular activities in $99 \%$ from 63 elementary school were already effective.

Frequency distribution of survey result of principal competences in managing character based extracurricular activities at 63 elementary school is shown in Table 2.

Table 2: Frequency distribution of scores in managing character based extracurricular activities

\begin{tabular}{lccc}
\hline \hline Scores & Frequency (fi) & $\begin{array}{l}\text { Relative } \\
\text { frequency } \\
(\%)\end{array}$ & $\begin{array}{c}\text { Cumulative } \\
\text { frequency } \\
(\%)\end{array}$ \\
\hline 11 & 1 & 1.6 & 1.6 \\
12 & 1 & 9.5 & 11.1 \\
13 & 11 & 88.9 & 100.0 \\
\hline Total & 63 & 100 & \\
\hline
\end{tabular}

In Table 2, it is shown that principal competence in managing character based extracurricular activities having scores higher than average scores was $88.9 \%$ and having scores lower than average scores was $11.1 \%$. It means that principal competences of managing character based extracurricular activities in $88.9 \%$ of 63 elementary schools were already effective.

\section{CONCLUSION AND SUGGESTION}

The findings showed that: (1) mean of character based extracurricular activities is 12.94 or $99 \%$ from theoretical 
masimum score achievement. It means that principal competences in managing character based extracurricular activities in $99 \%$ from 63 elementary school were already effective; (2) principal competence in managing character based extracurricular activities having scores higher than average scores was $88.9 \%$ and having scores lower than average scores was $11.1 \%$. It means that principal competences of managing character based extracurricular activities in $88.9 \%$ of 63 elementary schools were already effective. It is expected that all elementary schools in Jakarta integrate character values through extracurricular activities so that this activities can insert positive messages to them leading to the students having strong characters.

\section{REFERENCES}

[1] Anggraini, P. "The Implementation of character education model based on empowerment theatre for primary school students". Journal of Education and Practice, 7(1), 2016, 26-29.

[2] Benninga, J. S.; Berkowitz, M. W.; Kuehn, P.; \& Smith, K. "The relationship of character education implementation and academic achievement in elementary schools". Journal of Research in Character Education, 1(1), 2003, 19-32

[3] Chapman, A. M. "Implementing character education in school curriculum". Essai, Vol 9, 2011, Article 11, http://dc.cod.edu/essai/vol9/iss1/11

[4] Graff, C. E. "The effectiveness of character education programs in middle and high schools".Counselor Education Master's Theses. Paper 127,2012 ,

[5] Dwirahayu, G. "Implementation of character building education in mathematics teaching and learning to create of human character". Proceeding of International Seminar and the Fourth National Conference on Mathematics Education, 2011, ISBN: 978-979-16353-7 